\title{
Monitoring the expansion of Dermacentor reticulatus and occurrence of canine babesiosis in Poland in 2016-2018
}

\author{
Dorota Dwużnik-Szarek ${ }^{*}$, Ewa J. Mierzejewska' ${ }^{1}$ Anna Rodo², Katarzyna Goździk², Jolanta Behnke-Borowczyk4,
} Dorota Kiewra ${ }^{5}$, Natalia Kartawik ${ }^{4}$ and Anna Bajer ${ }^{1}$

\begin{abstract}
Background: The significance of tick-borne diseases has increased considerably in recent years. Because of the unique distribution of the tick species Dermacentor reticulatus in Poland, comprising two expanding populations, Eastern and Western that are separated by a Dermacentor-free zone, it is important to conduct studies on the process of tick expansion and emergence of canine babesiosis. The main aim of the current study was to monitor the expansion of D. reticulatus populations from spring 2016 to autumn 2018 to determine (1) the actual geographical range of this tick species, and (2) and the seasonal/annual shift in range limits and changes in distance between Western and Eastern populations of ticks (the size of the non-endemic area).
\end{abstract}

Methods: Ticks were collected in spring/autumn during a 3-year study. From each season and year at least three pairs of sites from the Western and Eastern populations were selected. Then the mean distance between paired sites was calculated for each season and year. We collected and analyzed data from veterinary clinics on the number of canine babesiosis cases treated in the clinic during a whole year (2018).

Results: Accordingly, further expansion of the two D. reticulatus populations was recorded, mainly along river basins. Marked colonization of the gap zone was observed, with a mean annual shift in the range of $2.5-10 \mathrm{~km}$ and a steadily decreasing distance between the two tick populations. The occurrence of babesiosis in different regions revealed low numbers of cases in Western Poland (19 cases/year) and the gap area (only 7 cases/year) and high incidence (up to 250 cases/1000 dogs) and fatality (total 3.65\%) in Central and Eastern Poland. Strong associations were found geographically between tick and babesiosis occurrence and temporally in the seasonal patterns of occurrence of ticks and outbreaks of babesiosis.

Conclusions: We documented the shift in range limits and continued process of colonization of the gap zone accompanied by the emergence of canine babesiosis in the Eastern expansion zone. Updated maps of the distribution of ticks and occurrence of babesiosis in different regions of Poland have allowed us to predict of the emergence of pathogens vectored by $D$. reticulatus.

Keywords: Dermacentor reticulatus, Abundance, Seasonality, Range, Babesia canis, incidence, Poland

\footnotetext{
*Correspondence: dorota.dwuznik@biol.uw.edu.pl

1 Department of Eco-Epidemiology of Parasitic Diseases, Institute of Developmental Biology and Biomedical Sciences, Faculty of Biology, University of Warsaw, Miecznikowa 1, 02-096 Warsaw, Poland

Full list of author information is available at the end of the article
}

\section{Background}

The geographical range of the ornate dog tick (Dermacentor reticulatus) in Europe is not contiguous and is divided into two metapopulations [1-4]. The Western metapopulation includes areas of France, Belgium, adaptation, distribution and reproduction in any medium or format, as long as you give appropriate credit to the original author(s) and the source, provide a link to the Creative Commons licence, and indicate if changes were made. The images or other third party material in this article are included in the article's Creative Commons licence, unless indicated otherwise in a credit line to the material. If material is not included in the article's Creative Commons licence and your intended use is not permitted by statutory regulation or exceeds the permitted use, you will need to obtain permission directly from the copyright holder. To view a copy of this licence, visit http://creativeco mmons.org/licenses/by/4.0/. The Creative Commons Public Domain Dedication waiver (http://creativecommons.org/publicdomain/ zero/1.0/) applies to the data made available in this article, unless otherwise stated in a credit line to the data. 
Slovakia, the Czech Republic, Netherlands and Germany [2, 5-8]. The Eastern metapopulation covers Lithuania, Latvia, Belarus, and the eastern and central parts of Poland, along with areas located west of the Vistula River and Russian territory right up to the Ural Mountains [2, 3, 9-11]. Thus, there are two populations of ornate dog ticks in Poland, separated by an area that historically has been free of this tick species (see map in [2]). However, the situation is not static, and in recent decades, geographic expansion of $D$. reticulatus has been recorded in many European countries, including Poland $[3,12]$.

In Poland (country size: $49^{\circ} 00^{\prime}-54^{\circ} 50^{\prime} \mathrm{N}$ and $14^{\circ} 07^{\prime}-$ $24^{\circ} 09^{\prime} \mathrm{E}$ ), detailed monitoring of the expansion of this tick species was carried out in 2012-2014 [2]. We confirmed the spread of the Eastern Polish population of the tick in a western direction and the expansion of the Western Polish population in an eastern direction. At that time, the easternmost record of the Western population of D. reticulatus was near Kościan (Greater Poland Voivodeship, $61 \mathrm{~km}$ from the proximate bank of the Oder River and $129 \mathrm{~km}$ from the western border of the country); in the eastern area of Poland, the ticks spread to Rawa Mazowiecka and Rzeczyca (Łódź Voivodeship). Finally, the $D$. reticulatus-free zone (in which only negative sites were recorded) was located at the time in the central parts of the country and covered about 150,000 $\mathrm{km}^{2}$, from West Pomerania and Pomerania Voivodeships in Northern Poland, to Opole, Silesia, Lesser Poland and Subcarpatia Voivodeships in Southern Poland [2].

The factors responsible for the existence of this tickfree zone (gap) are not known. One hypothesis is that there is a lack of suitable habitats for D. reticulatus (wasteland, fallow land, and submerged meadows) in the gap zone [13-15]. Intensive agricultural practices are known to have had a negative impact on tick occurrence and density [16], including the density of $D$. reticulatus populations $[15,17]$. However, this cannot be the only reason for $D$. reticulatus expansion into this previously tick-free zone. Rapid expansion of this tick species across the country is likely to lead to the colonization of the gap zone and eventually to a fusion of the Western and the Eastern D. reticulatus populations [18]. Determination of the current range of this tick is particularly important due to the epidemiological threat from pathogens transmitted by $D$. reticulatus $[19,20]$.

One of the most significant pathogens vectored by $D$. reticulatus is Babesia canis, the causative organism of canine babesiosis $[21,22]$. The prevalence of $B$. canis in D. reticulatus is in the range of $1-4 \%$ in Poland and varies depending on the region of the country $[14,23]$. Ticks infected with B. canis were recorded in North Eastern Poland, in Central Poland including in the Eastern expansion zone on the western side of the Vistula River and Eastern or South Eastern areas of Poland [14, 2326]. Interestingly, to date no B. canis-positive $D$. reticulatus ticks have been found in Western Poland [14, 27] (Dwużnik and Kiewra unpublished). Canine babesiosis has spread in Poland over the last $10-15$ years [14, 28-32], becoming a serious problem particularly for dog owners and veterinarians in regions where previously it was not known to exist [21, 24, 32].

The drug of choice for treatment of babesiosis is imidocarb dipropionate, which has been used with good efficacy in Babesia endemic regions [33, 34] including Poland (such as Imizol injection, Intervet International, Boxmeer, Netherlands). The response to imidocarb is a good indicator for field diagnosis of babesiosis and diagnosis conducted on the basis of clinicopathological findings has a high accuracy rate $[35,36]$. Hence, monitoring of the use of Imizol in veterinary clinics is a valuable tool in the study of the epidemiology of canine babesiosis, and reports from local veterinary clinics of the occurrence of canine babesiosis can inform on the distribution of $D$. reticulatus, as this tick species is the main vector of $B$. canis $[36,37]$. Veterinary practitioners (VP) are the first to notice the emergence of cases and to implement prevention measures for tick-borne diseases [38]. Babesiosis is a serious problem from a veterinary perspective, not only in endemic areas, but perhaps even more so in locations to which the tick vector has recently spread, where there will be less experience with this disease among both VP and dog owners [39-41]. Knowledge of the current range of $D$. reticulatus ticks is therefore necessary to assess the risk of infection with $B$. canis $[36,42]$.

The main aim of our study was to monitor the expansion of two Polish $D$. reticulatus populations from spring 2016 to autumn 2018, with a particular focus on the colonization of the gap zone. Regular field collections were performed to determine (1) the actual geographical range of the tick, and (2) the seasonal/annual shift in range limits and changes in size of the non-endemic area. Additionally, we collected data on the distribution and seasonal emergence of canine babesiosis in Poland, including both areas that are endemic (Western and Eastern) and non-endemic for $D$. reticulatus ticks. Finally, we compiled an updated map of the distribution of babesiosis in different regions of Poland, together with the distribution/occurrence of the tick $D$. reticulatus.

\section{Methods \\ Monitoring the present range of occurrence of the $D$. reticulatus ticks}

The methods used for tick collection have been described previously in detail [2]. In short, we monitored tick occurrence at two peaks of $D$. reticulatus activity (spring and autumn) for 3 years: 2016, 2017 and 2018 (Additional 
file 1: Table S1). Locations for monitoring were selected within the previous range of $D$. reticulatus [2] to confirm the persistence of populations, and along the borders of the previous range to detect the spread of $D$. reticulatus (Additional file 1: Table S1). A representative number of locations (22\%) were visited two or more times to confirm maintenance of ticks in these new sites, especially in the expansion zones, and to collect ticks for further molecular research. In each location, preferred tick habitats were checked, including fallow land, clearings, wasteland, pastures, river basins, etc. Ticks were collected by dragging using the $1 \mathrm{~m}^{2}(1.2 \mathrm{~m} \times 0.8 \mathrm{~m})$ woolen blanket, and from the researchers' clothing and directly from vegetation. After every dragging, scrupulous examination of blankets and clothes was undertaken in order to prevent the transfer of ticks onto the next location. The collection of ticks took place mainly during the morning and afternoon hours. The size of inspected areas varied from $50 \mathrm{~m}^{2}$ (endemic areas with high tick abundance) to 1200 $\mathrm{m}^{2}$ (expansion zones, gap). Inspected sites were classified as "D. reticulatus-positive" if at least one adult tick was collected or as "D. reticulatus-absent" if not a single tick was collected from the woolen blanket, researchers' clothes or vegetation. After confirming the presence of $D$. reticulatus in new locations, new sites were surveyed in a 20-60 km radius, until a "D. reticulatus-absent" location was found.

Tick densities were calculated per $100 \mathrm{~m}^{2}$. Mean abundance of questing $D$. reticulatus was calculated for every location. Ticks were identified as male/female and preserved at a temperature of $-20{ }^{\circ} \mathrm{C}$ in the Department of Parasitology, Faculty of Biology, University of Warsaw.

\section{Distance between Eastern and Western populations of $D$. reticulatus and shift in range}

To evaluate the colonization of the tick-free zone (gap), we calculated the distance between two tick populations (Eastern and Western). For this, two sites on the outer border of " $D$. reticulatus-positive" sites (in a particular season) were selected, one from the Eastern and one from the Western population, along the East-West axis: the most eastward located site from the Western population and the most westward located site from the Eastern population. From each season (spring/ autumn) and year of the study (2016, 2017, 2018), at least three pairs of sites from the Western and Eastern populations were selected. Then the mean distance between paired sites for each season and year was calculated (see below).

Additionally, the shift in the tick range was estimated in successive seasons for both populations. For this, we calculated the change in distance between two border " $D$. reticulatus-positive" sites within each population in two subsequent seasons: between sites at the most eastward (for Western population) and most westward (for Eastern population) location at the range border. All distance calculations were based on Google Maps (https://maps. google.com) and the Polish Geoportal website: (https:// www.geoportal.gov.pl/). The maps presented in this paper were designed using the ArcGIS (ESRI) geoinformatic software.

\section{Seasonal abundance of $D$. reticulatus in endemic area}

In order to assess the seasonal pattern of $D$. reticulatus abundance, we used data from our long-term study (2012-2016) on tick abundance in several sites in the endemic region of the Eastern population [2, 16, 17, unpublished data]. We also used data collected from seven sites from the current study (2016-2018): Stoski, Kury, Siekierki, Białobrzegi, Korabiewice Owadów, Żyrardów (coordinates in Additional file 1: Table S1). Altogether, data originated from 14 sites [2, 16, 17, unpublished data] and current study.

Tick collections were carried out at these sites from spring 2012 to autumn 2018; in total, mean abundance for each month was calculated based on 4-14 collections (days) each month. Ticks were collected for 6 months of every year, encompassing two tick activity periods: in spring (March, April, May) and autumn (September, October, November). Additionally, in 2017 and 2018, the first appearance of $D$. reticulatus ticks in spring was recorded in one of endemic sites (Stoski or Urwitałt).

\section{Statistical analyses}

The IBM SPSS Statistics v. 21 software package (IBM Corporation) was applied for all analyses. General linear models were used for the analysis of the mean tick abundance, using models with normal errors, incorporating: YEAR (2016, 2017, 2018), SEASON (spring/autumn) and REGION (Eastern, Eastern expansion zone, Western, Western expansion zone).

\section{The distribution and incidence of canine babesiosis in different regions of Poland in 2018}

Our project partners (VP) provided the number of new clinical cases of babesiosis diagnosed in 2018. In two clinics (Tłuszcz, Cegłów, both in D. reticulatus Eastern population range), cases were counted prospectively in 2018. Data from other project partners were obtained in 2019 (retrospective survey).

We collected and analyzed data on the number of babesiosis cases treated in the clinic during the whole year (2018) by month, the number of fatal cases due to babesiosis during the whole year (2018) by month, and finally the exact or estimated number of dogs presenting at the clinic during the whole year 2018. 


\section{Definition of cases}

Cases were defined as clinical cases of babesiosis when diagnosed by the VP in their practice over the course of a year (2018). Microscopic examination of stained blood smears from capillary beds is rarely performed in babesiosis-endemic regions, due to the need for rapid treatment, so no laboratory confirmation of Babesia infection was required. Thus, the collected data represent the exact number of treated clinical babesiosis cases (confirmed or not by laboratory examination) or the number of cases treated successfully with imidocarb dipropionate (Imizol) as recorded in clinics. In total, data from 47 clinics were georeferenced for the construction of a distribution map (Table 5). Cases were assigned to three regions (Eastern, Western and gap) by postcode according to the current D. reticulatus range (Fig. 4).

Based on the number of reported treated/fatal cases, several indices were calculated: (1) the annual incidence of canine babesiosis; (2) incidence of canine babesiosis; (3) fatality as \% of dogs with fatal outcome; (4) the total number of babesiosis cases/month is presented for seasonal distribution of cases.

\section{Results}

Altogether, 466 tick collections on 330 sites were performed during the 3-year study (Additional file 1: Table S1), including 123, 168 and 175 collections in 2016, 2017 and 2018, respectively. Among these, 48, 55 and 49 new $D$. reticulatus-positive locations were found in 2016, 2017 and 2018, respectively (Fig. 1a-c). In addition to our previous monitoring in 2012-2014 [2], ticks were found in a number of new sites in eight out of 16 voivodeships: Lower Silesia (30 new sites), Kuyavia-Pomerania (6), Lubusz (20), Łódź (29), Mazovia (34), Greater Poland (25), Holy Cross (1) and West Pomerania (7) (sites listed in Additional file 1: Table S1). 5130 ticks were collected, including 2836 females and 2294 males.

\section{Current range of the tick $D$. reticulatus}

Monitoring of the occurrence of D. reticulatus in the area between the Vistula River and the western border of Poland in 2016-2018 revealed seasonal and annual changes in the spatial distribution of this tick species and persistence of the gap zone between the two tick populations (Fig. 1a-c). The current range of D. reticulatus in Poland based on the data from our three years of monitoring is shown in Fig. 1d.

\section{Expansion of the Eastern population in the western, southern and northern directions}

Many new $D$. reticulatus-positive locations were found in each season and year of the study in the Eastern expansion zone (Fig. 1a-c): 8, 28 and 24 new sites in 2016, 2017 and 2018, respectively. The main directions of the expansion can be seen in Fig. 1a-c. The majority of the new $D$. reticulatus-positive sites were discovered to the west of previously positive sites (2012-2014), along several river basins, especially along the Bzura River (more than ten new sites) and Pilica River (eight new sites) (both are western tributaries of the Vistula [pol.: Wisła] River) (Fig. 1a-c). Finally, the most westward $D$. reticulatus-positive sites along the Pilica and Bzura river basins were located about $3 \mathrm{~km}$ from the riverbeds (close to Tomaszów Mazowiecki and Łęczyca), approximately 120 and $135 \mathrm{~km}$ from the Vistula River, respectively (Fig. 1c). In comparison to the previous study (20122014; [2].), in which the western border of the Eastern population was found $60 \mathrm{~km}$ from the basin of the Vistula River, in the current study the most distant positive site (Sławoszewek, Table 1) was found in spring 2018 as far as $124 \mathrm{~km}$ from the Vistula River and $25 \mathrm{~km}$ to the north of the Warta River (Fig. 1c).

Expansion of the Eastern population was also observed in a southerly direction: in spring 2016 the most southward $D$. reticulatus-positive site was found near Trębowiec Krupów in Holy Cross Voivodeship (the first positive site in this voivodeship). Ticks were also collected at this site in subsequent seasons and years of the study (Fig. 1a-c; Additional file 1: Table S1).

Northward expansion was confirmed by the identification of new D. reticulatus-positive sites in KuyaviaPomerania Voivodeship, with the northernmost site discovered at the bank of the Brda River (a western tributary of the Vistula River), approximately $25 \mathrm{~km}$ westward from the Vistula River and about $20 \mathrm{~km}$ to the north of Bydgoszcz (Fig. 1b).

\section{Expansion of the Western population in eastern, southern and northern directions}

With regard to the Western expansion zone, ticks were detected in 26, 30 and 39 sites in 2016, 2017 and 2018, respectively. Altogether, $D$. reticulatus-positive locations were found in five voivodeships: Lubusz (19 sites), Lower Silesia (27), Greater Poland (33) and West Pomerania (16), many more than in the previous monitoring period (2012-2014; [2]).

In each voivodeship, D. reticulatus-positive locations were discovered mostly in close proximity to the riverbeds (Fig. 1a-c). Expansion in an easterly direction along the Barycz River was confirmed by 13 new positive locations. Expansion in a southerly direction occurred along the Bystrzyca and Oder [pol.: Odra] rivers (Fig. 1a-c). Expansion to the north was noted along the Obra River (11 new D. reticulatus-positive sites situated along the river basin). The most eastward tick-positive sites were 
a

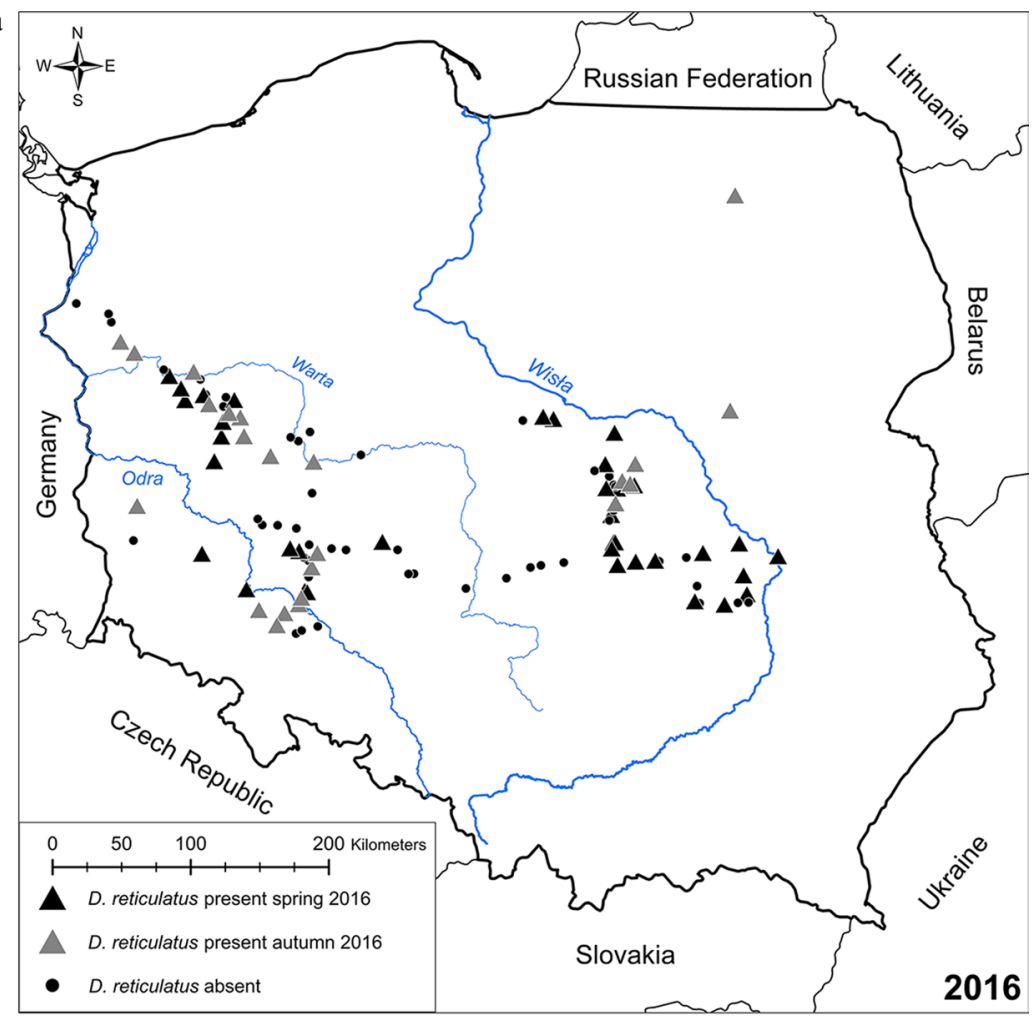

b

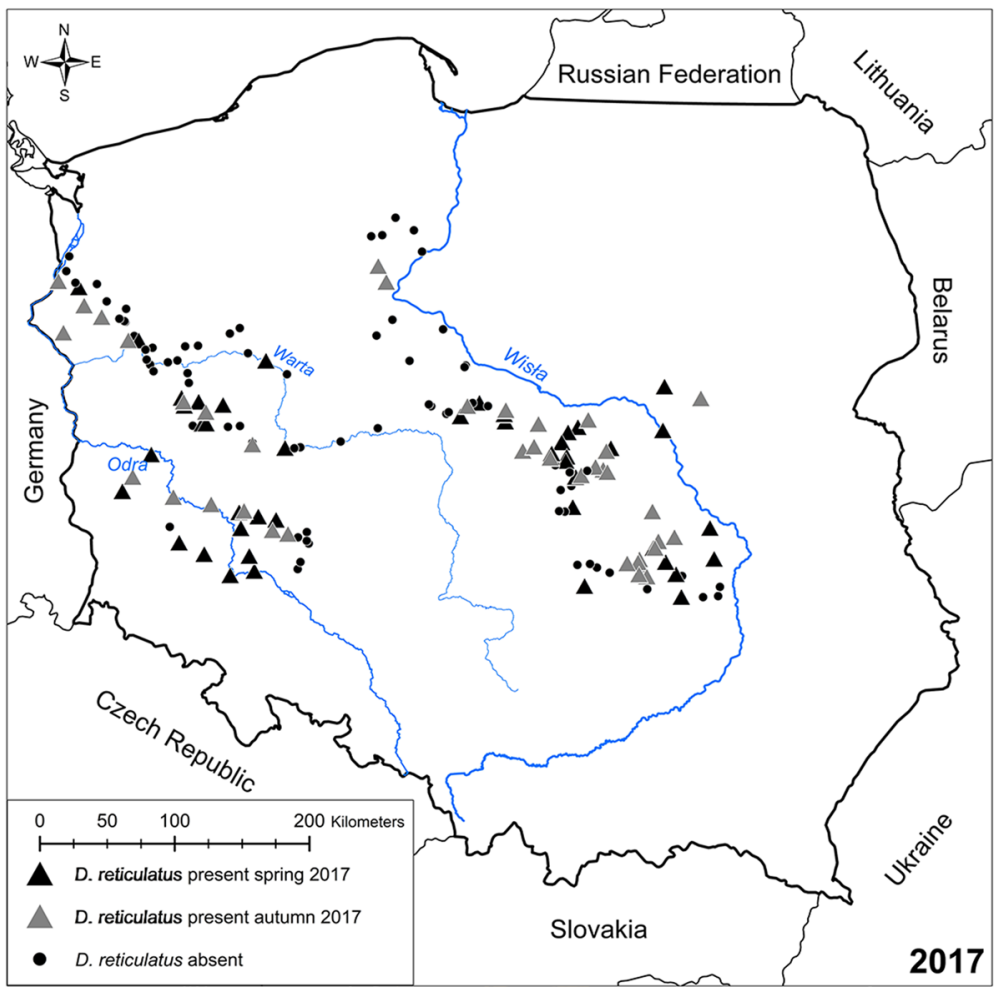

Fig. 1 Inspected sites in a 2016, b 2017, c 2018, and d current range of D. reticulatus in Poland 
c
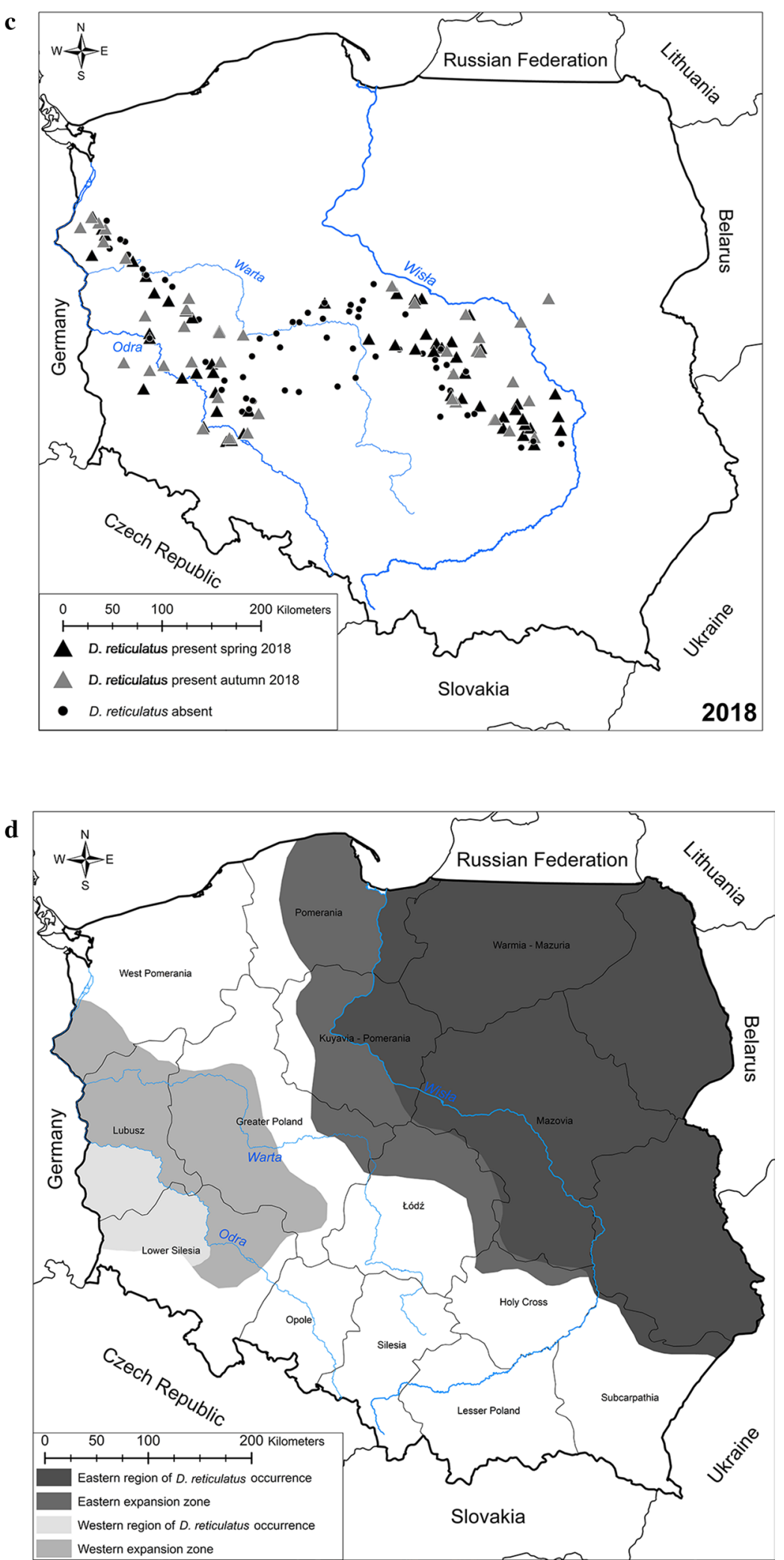

Fig. 1 continued 
Table 1 Distance of the borders of "D. reticulatus-positive" sites within the Eastern population in successive seasons: between sites at the most westward locations

\begin{tabular}{|c|c|c|c|c|c|c|}
\hline Season & Latitude & Longitude & Season & Latitude & Longitude & Distance (km) \\
\hline Spring 2016 & & & Autumn 2016 & & & \\
\hline Bolimów & 52.08176 & 20.1712 & Stare Budy & 52.07974 & 20.48895 & -21.7 \\
\hline \multirow[t]{2}{*}{ Rawiczów } & 51.9253 & 20.1779 & Korabiewice & 51.95094 & 20.42969 & -17.6 \\
\hline & & & & & & Mean \pm S.E. $-19.65 \pm 2.05$ \\
\hline Autumn 2016 & & & Spring 2017 & & & \\
\hline Wygoda & 51.970261 & 20.34676 & Dębowa Góra & 51.90550 & 20.12974 & 16.5 \\
\hline Stare Budy & 52.079737 & 20.48895 & Dąbkowice & 52.06508 & 19.87396 & 42.1 \\
\hline \multirow[t]{2}{*}{ Petrynów } & 51.704731 & 20.09357 & Nowy Kurzeszyn & 51.825767 & 20.27326 & 18.3 \\
\hline & & & & & & Mean \pm S.E. $25.67 \pm 11.00$ \\
\hline Spring 2017 & & & Autumn 2017 & & & \\
\hline Ryków & 51.317265 & 20.76844 & Krakowa Góra & 51.32158 & 20.66409 & 7.28 \\
\hline Gole & 52.406193 & 19.09193 & Cetty & 52.38489 & 18.96138 & 9.18 \\
\hline Dąbkowice & 52.065077 & 19.87396 & Oszkowice & 52.08343 & 19.56167 & 21.5 \\
\hline \multirow[t]{2}{*}{ Dębowa Góra } & 51.905501 & 20.12974 & Strzyboga & 51.91628 & 20.18895 & 4.2 \\
\hline & & & & & & Mean \pm S.E. $8.44 \pm 6.90$ \\
\hline Autumn 2017 & & & Spring 2018 & & & \\
\hline Cetty & 52.384885 & 18.96138 & Sławoszewek & 52.3935 & 18.18320 & 52.9 \\
\hline Oszkowice & 52.083434 & 19.56167 & Chwalborzyce & 52.0681 & 18.83970 & 48.3 \\
\hline \multirow[t]{2}{*}{ Strzyboga } & 51.916276 & 20.18895 & Nowe Rowiska & 51.90006 & 20.12697 & 4.62 \\
\hline & & & & & & Mean \pm S.E. $35.27 \pm 20.44$ \\
\hline Spring 2018 & & & Autumn 2018 & & & \\
\hline Sławoszewek & 52.3935 & 18.18320 & Skoki & 52.39507 & 19.51830 & -90.7 \\
\hline Chwalborzyce & 52.0681 & 18.83970 & Słomków & 51.95529 & 19.98709 & -79.6 \\
\hline Teofilów & 51.5242 & 20.19500 & Tomaszów Mazowiecki & 51.52180 & 20.05790 & 9.53 \\
\hline \multirow[t]{3}{*}{ Rawa Mazowiecka } & 51.75236 & 20.24912 & Łochów2 & 51.74892 & 20.07967 & 11.8 \\
\hline & & & & & & Mean \pm S.E. $-37.24 \pm 47.91$ \\
\hline & & & & & & TOTAL \pm S.E. $2.50 \pm 24.76$ \\
\hline
\end{tabular}

detected in the first year of current monitoring: located in Greater Poland Voivodeship about 71, 88 and about $200 \mathrm{~km}$ from the Barycz River, Oder River and the western border of the country, respectively (Fig. 1a).

In the north, a new limit to the distribution of D. reticulatus was a positive site recorded in West Pomerania Voivodeship, only $30 \mathrm{~km}$ to the south of Szczecin, less than three $\mathrm{km}$ to the Oder River (Fig. 1b-c). In the south, the border was recorded in Lower Silesia Voivodeship, in close proximity to Wrocław in the Bystrzyca River basin, close to the western bank of the Oder River (Fig. 1c).

\section{Seasonal distance of expansion/regression}

In addition to the marked expansion of the range of $D$. reticulatus across the 3-year period, we also recorded dynamic seasonal changes to the limits of tick distribution, and therefore we calculated the distances for seasonal shifts of the borders of tick ranges: expansion or regression distance for both tick populations.

\section{Eastern population}

Distances were measured between the two closest positive sites in successive seasons, localized along the main axis of the shift (East-West), for at least two pairs of sites following each summer (from spring to autumn) and winter (from autumn to spring). Mean distances are presented in Table 1. Generally, the individual distances of expansion for site pairs (shift in the range causing expansion outside current range) ranged between 4 and $53 \mathrm{~km}$, and expansion was recorded mostly following winter: new sites were found outside the current range in spring 2017 and 2018 but also in autumn 2017. However, in autumn 2016 and 2018, positive sites were found within the previous range, causing "regression" in the range from about 21 to $91 \mathrm{~km}$. Thus, the mean distance of expansion/regression for subsequent seasons ranged between $-37 \mathrm{~km}$ and $+35 \mathrm{~km}$, and overall mean expansion distance was $+2.50 \pm 24.8 \mathrm{~km} /$ season. 


\section{Western population}

The mean between-season distances for sites in Western Poland are presented in Table 2. Generally, individual distances for expansion of site pairs (shift to the east in the range causing expansion outside the current range) ranged between 4 and $65 \mathrm{~km}$, and expansion was recorded following the summer of 2016 and winter of 2016/2017, and also for two site pairs following the winter of $2017 / 2018$ and the following summer 2018. However, in autumn 2017 and spring 2018, positive sites were found within the previous range, causing 'regression' in the range from about 8 to $31 \mathrm{~km}$. Thus, the mean distance for successive seasons ranged between $-16 \mathrm{~km}$ and $+34 \mathrm{~km}$, and the overall mean distance of expansion over the three year study was $+10.15 \pm 15.8 \mathrm{~km} /$ season.

\section{Distance between the Eastern and Western populations of $D$. reticulatus}

Because of the recorded expansion of both tick populations, as described above, we also calculated changes in the width of the gap zone, by calculating the distances between pairs of $D$. reticulatus positive sites, one from the Eastern population, one from the Western one.

The width of the tick-free area was estimated by the distance between the two monitored $D$. reticulatus populations. The mean width for all seasons was $206.25 \pm 17.17$ $\mathrm{km}$ (Table 3). Generally, a shorter mean distance between the two regions was recorded in spring compared to autumn (Table 3). The longest mean distance between populations was observed in the first year of monitoring, in autumn $2016(239.5 \pm 15.50 \mathrm{~km})$ (Table 3). The shortest mean distance between Western and Eastern populations of $D$. reticulatus was recorded in the last season of

Table 2 Distance of the borders of "D. reticulatus-positive" sites within the Western population in successive seasons: between sites at the most eastward locations

\begin{tabular}{|c|c|c|c|c|c|c|}
\hline Season & Latitude & Longitude & Season & Latitude & Longitude & Distance (km) \\
\hline Spring 2016 & & & Autumn 2016 & & & \\
\hline Skwierzyna & 52.61080 & 15.52440 & Zamyślin & 52.64594 & 15.78013 & 17.8 \\
\hline Kuźnica Zbącka & 52.23180 & 16.10573 & Grodzisk Wielkopolski & 52.23941 & 16.34532 & 16.4 \\
\hline \multirow[t]{2}{*}{ Obra } & 52.06911 & 16.04106 & Bonikowo & 52.11618 & 16.63196 & 40.8 \\
\hline & & & & & & $\begin{array}{l}\text { Mean } \pm \text { S.E. } \\
25.00 \pm 10.53\end{array}$ \\
\hline Autumn 2016 & & & Spring 2017 & & & \\
\hline Baczyna & 52.74998 & 15.13779 & Janczewo & 52.76611 & 15.34509 & 14 \\
\hline Zamyślin & 52.64595 & 15.78013 & Sobota & 52.66563 & 16.75029 & 64.6 \\
\hline \multirow[t]{2}{*}{ Bonikowo } & 52.11619 & 16.63196 & Śrem & 52.08752 & 16.98591 & 24.4 \\
\hline & & & & & & $\begin{array}{l}\text { Mean } \pm \text { S.E. } \\
34.33 \pm 20.18\end{array}$ \\
\hline Spring 2017 & & & Autumn 2017 & & & \\
\hline Janczewo & 52.76611 & 15.34509 & Gorzów Wielkopolski & 52.76383 & 15.23103 & -7.7 \\
\hline Chojna & 53.12995 & 14.42094 & Banie & 53.097498 & 14.65297 & -16.00 \\
\hline \multirow[t]{2}{*}{ Kościan } & 52.10445 & 16.63240 & Śrem & 52.08753 & 16.98591 & -24.4 \\
\hline & & & & & & $\begin{array}{l}\text { Mean } \pm \text { S.E. } \\
-16.03 \pm 5.58\end{array}$ \\
\hline Autumn 2017 & & & Spring 2018 & & & \\
\hline Chojna & 53.12995 & 14.42094 & Banie & 53.09980 & 14.66880 & 16.9 \\
\hline Rów & 52.97834 & 14.72285 & Tarnowo & 52.99290 & 14.82220 & 6.85 \\
\hline \multirow[t]{2}{*}{ Niezgoda } & 51.51415 & 17.04281 & Wierzchowice Wielkie & 51.55975 & 16.60470 & -30.8 \\
\hline & & & & & & $\begin{array}{l}\text { Mean } \pm \text { S.E. } \\
-2.35 \pm 18.97\end{array}$ \\
\hline Spring 2018 & & & Autumn 2018 & & & \\
\hline Biedaszków Mały & 51.39967 & 17.09867 & Czeszów & 51.37780 & 17.24220 & 10.3 \\
\hline Psary & 51.19400 & 17.03333 & Poligon Cienin & 51.20000 & 17.08910 & 3.95 \\
\hline \multirow[t]{3}{*}{ Trzciel } & 52.371869 & 15.86673 & Chmielinko & 52.40400 & 16.16590 & 20.6 \\
\hline & & & & & & $\begin{array}{l}\text { Mean } \pm \text { S.E. } \\
11.62 \pm 5.99\end{array}$ \\
\hline & & & & & & $\begin{array}{l}\text { TOTAL Mean } \pm \text { S.E. } \\
10.51 \pm 15.76\end{array}$ \\
\hline
\end{tabular}


Table 3 Distances between the two tick populations (Eastern and Western)

\begin{tabular}{|c|c|c|c|c|c|c|c|}
\hline Season & Western population & Latitude & Longitude & Eastern population & Latitude & Longitude & Distance (km) \\
\hline \multirow[t]{5}{*}{ Spring 2016} & Konin & 52.47340 & 16.22720 & Gostynin & 52.39550 & 19.51830 & 223.00 \\
\hline & Odolanów & 51.57530 & 17.82900 & Inowłódz & 51.53160 & 20.22590 & 167.00 \\
\hline & Wiszna Mała2 & 51.23710 & 17.05790 & Lubiszów Kolonia & 51.42360 & 20.28240 & 225.00 \\
\hline & Wiszna Mała2 & 51.23710 & 17.05790 & Trębowiec Krupów & 51.17530 & 21.07630 & 283.00 \\
\hline & & & & & & & $\begin{array}{l}\text { Mean } \pm \text { S.E. } \\
224.50 \pm 29.50\end{array}$ \\
\hline \multirow[t]{3}{*}{ Autumn 2016} & Bonikowo & 52.116186 & 16.63196 & Puszcza Mariańska & 51.970261 & 20.34676 & 255.00 \\
\hline & Biedaszków Mały & 51.399664 & 17.09868 & Nowy Kurzeszyn & 51.825765 & 20.27326 & 224.00 \\
\hline & & & & & & & $\begin{array}{l}\text { Mean } \pm \text { S.E. } \\
239.5 \pm 15.50\end{array}$ \\
\hline \multirow[t]{5}{*}{ Spring 2017} & Słonawy & 52.66564 & 16.75028 & Katarzyna & 52.31615 & 18.88637 & 150.00 \\
\hline & Śrem & 52.08752 & 16.98591 & Dąbkowice & 52.06508 & 19.87396 & 198.00 \\
\hline & Kowaliki & 51.60618 & 16.91092 & Petrynów & 51.70473 & 20.09357 & 220.00 \\
\hline & Brzeg Dolny & 51.26023 & 16.69593 & Podkońska Wola & 51.17607 & 20.20582 & 245.00 \\
\hline & & & & & & & $\begin{array}{l}\text { Mean } \pm \text { S.E. } \\
203.25 \pm 29.25\end{array}$ \\
\hline \multirow[t]{5}{*}{ Autumn 2017} & Lubiczyn & 53.12995 & 14.42094 & Koronowo & 53.31464 & 17.96716 & 237 \\
\hline & Gorzów Wielkopolski & 52.76383 & 15.23103 & Osielsk & 53.20956 & 18.05884 & 195.00 \\
\hline & Nowy Tomyśl & 52.30958 & 16.11307 & Cetty & 52.38489 & 18.96138 & 193.00 \\
\hline & Kościan & 52.10445 & 16.63240 & Oszkowice & 52.08343 & 19.56167 & 200.00 \\
\hline & & & & & & & $\begin{array}{l}\text { Mean } \pm \text { S.E. } \\
206.25 \pm 15.38\end{array}$ \\
\hline \multirow[t]{4}{*}{ Spring 2018} & Trzciel & 52.37187 & 15.86673 & Sławoszewek & 52.39350 & 18.18320 & 156 \\
\hline & Śrem & 52.08880 & 16.98710 & Chwalborzyce & 52.06810 & 18.83970 & 127.00 \\
\hline & Biedaszków Mały & 51.39966 & 17.09868 & Kaczka & 51.55181 & 20.03962 & 205.00 \\
\hline & & & & & & & $\begin{array}{l}\text { Mean } \pm \text { S.E. } \\
162.67 \pm 28.22\end{array}$ \\
\hline \multirow[t]{5}{*}{ Autumn 2018} & Chmielinko & 52.40400 & 16.16590 & Dębniaki & 52.55046 & 19.18276 & 205.00 \\
\hline & Śrem & 52.08880 & 16.98710 & Słomków & 51.95529 & 19.98709 & 203.00 \\
\hline & Czeszów & 51.37780 & 17.24220 & Tomaszów Mazowiecki & 51.52180 & 20.05790 & 196.00 \\
\hline & & & & & & & $\begin{array}{l}\text { Mean } \pm \text { S.E. } \\
201.33 \pm 3.56\end{array}$ \\
\hline & & & & & & & $\begin{array}{l}\text { TOTAL Mean } \pm \text { S.E. } \\
206.25 \pm 17.17\end{array}$ \\
\hline
\end{tabular}

monitoring, spring 2018, only $162.67 \pm 28.22 \mathrm{~km}$ (Table 3 ). The shortest distances between two particular locations from the Eastern and Western tick populations were noted in spring 2017 and spring 2018: only $150 \mathrm{~km}$ between Słonawy (Western population) and Katarzyna (Eastern population) and $156 \mathrm{~km}$ between Trzciel (Western population) and Sławoszewek (Eastern population) (Table 3). The longest distance $(283 \mathrm{~km})$ was recorded in spring 2016 between Wiszna Mała 2 and Trębowiec Krupów (Table 3).

\section{Comparison of the mean abundance of $D$. reticulatus between four regions (Western and Eastern endemic areas with their expansion zones)}

The density of ticks per $100 \mathrm{~m}^{2}$ was determined at each site (Additional file 1: Table S1) and compared between seasons, years and four regions. Overall mean abundance of $D$. reticulatus was similar in spring and autumn $(7.13 \pm 1.13$ and $6.78 \pm 1.52$, respectively) (NS). There was a significant difference in mean abundance of $D$. reticulatus between years, mean density being highest in 2018 and lowest in $2017(8.97 \pm 0.1 .25$ and $4.53 \pm 1.50$, respectively) (main effect of YEAR on abundance of ticks: $F_{2,272}=2.59, P=0.07$ ) (Fig. 2a). Significantly higher abundance was observed in both known $D$. reticulatus endemic regions in comparison to expansion zones (main effect of REGION on abundance of ticks: $F_{3,272}=10.26$, $P<0.0001$ ) (Fig. 2b).

Depending on the year and season of the study, mean abundance was highest in the Eastern or Western endemic regions, but generally was lowest in the Eastern 


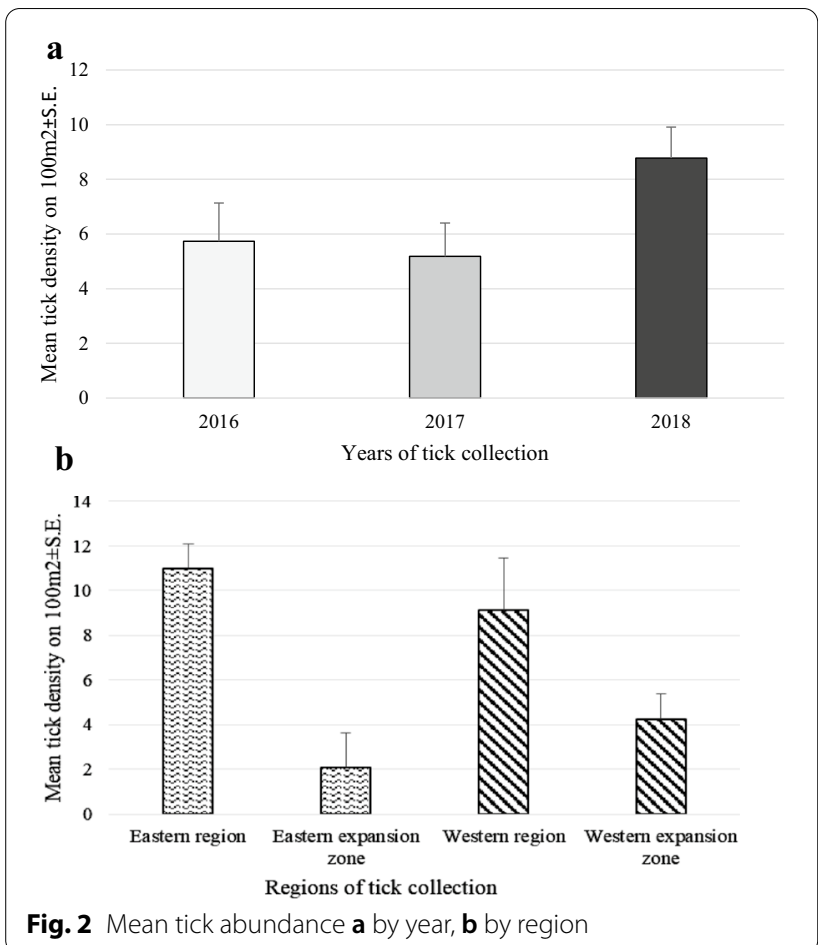

Table 4 Mean tick density by year $x$ season $x$ region

\begin{tabular}{llll}
\hline Year & Season & Region & Mean \pm S.E. \\
\hline 2016 & Spring & Eastern region & $5.59 \pm 2.52$ \\
& & Eastern expansion zone & $2.09 \pm 4.17$ \\
& Western region & $23.67 \pm 7.80$ \\
& Western expansion zone & $4.65 \pm 3.06$ \\
& Autumn & Eastern region & $15.80 \pm 4.17$ \\
& Eastern expansion zone & $1.50 \pm 11.03$ \\
& Western region & $4.05 \pm .5 .52$ \\
& Western expansion zone & $1.72 \pm 3.06$ \\
& Spring & Eastern region & $12.88 \pm 2.41$ \\
& Eastern expansion zone & $1.16 \pm 3.19$ \\
& Western region & $5.03 \pm 5.52$ \\
& Wutumn & Western expansion zone & $2.01 \pm 2.68$ \\
& Eastern region & $5.08 \pm 2.76$ \\
& Eastern expansion zone & $0.93 \pm 3.68$ \\
& Western region & $5.38 \pm 7.80$ \\
& Western expansion zone & $3.74 \pm 3.06$ \\
& Spring & Eastern region & $13.29 \pm 2.30$ \\
& & Eastern expansion zone & $3.92 \pm 2.60$ \\
& & Western region & $8.34 \pm 4.50$ \\
& & Western expansion zone & $2.98 \pm 2.35$ \\
& & Eastern region & $19.85 \pm 3.33$ \\
& Eastern expansion zone & $0.25 \pm 4.50$ \\
& Western region & $13.05 \pm 4.93$ \\
& & $10.07 \pm 2.68$ \\
\hline & &
\end{tabular}

or Western expansion zones (YEAR $\times$ REGION $\times$ SEASON on abundance of ticks: $F_{6,272}=2.24, P=0.04$ ) (Table 4).

\section{Seasonal abundance of $D$. reticulatus in the Eastern population area}

Seasonal abundance of $D$. reticulatus in optimal habitats over a 7-year period is presented in Fig. 3. The highest annual mean density of $D$. reticulatus in endemic areas was observed in $2015(38.82 \pm 8.07)$ and the lowest in $2012(2.03 \pm 4.57)$ (main effect of YEAR on tick abundance: $F_{6,135}=2.25, P=0.02$ ). The highest seasonal mean abundance was recorded in March (mean abundance $=42.27 \pm 5.30$ ) and April. In autumn, the highest density (about 18-19 ticks/100 $\mathrm{m}^{2}$ ) was observed in September and October (Fig. 3).

\section{Occurrence of canine babesiosis Raw data collection}

Data regarding canine babesiosis were collected from 47 clinics from three main regions of Poland (Fig. 4; Table 5), covering an estimated 79,204 dogs, including 11 small clinics (reporting 300-999 dogs annually), 20 clinics taking care of 1000-1500 dogs annually and 16 large clinics (1520-5500 dogs). The total number of babesiosis cases registered in 2018 by the VP was 1558 , with the vast majority of cases $(n=1532)$ from Eastern and Central Poland (Eastern population/region of $D$. reticulatus) (Table 5). Only 19 cases of babesiosis were reported from Western Poland (Western population/region of D. reticulatus), and only seven cases were reported from clinics located in the gap zone, outside the current range of the tick $D$. reticulatus (Table 5).

\section{Annual incidence of babesiosis}

The overall annual incidence of clinical babesiosis among the Polish dog population was 19.67/1000 dogs (1.97\%), with marked differences among three regions of the country (Table 5). The annual incidence was low (less than 1 case per 1000 dogs) in Western Poland (new endemic region for ornate dog tick) and in an area historically free of this tick species. Incidence was 100 times as high (52.74/1000) among dogs from Eastern and Central Poland (Eastern tick population) (Table 5). In this region, incidence varied between 100 and 240 cases/1000 dogs in five clinics (10-24\% of attending dogs); 24-82 cases/1000 dogs in 10 clinics and $0.7-19$ cases/1000 dogs in eight clinics (Table 5). In the two remaining regions with overall low incidence, incidence varied only between 0 and 3.0 cases/1000 dogs (Table 5). 


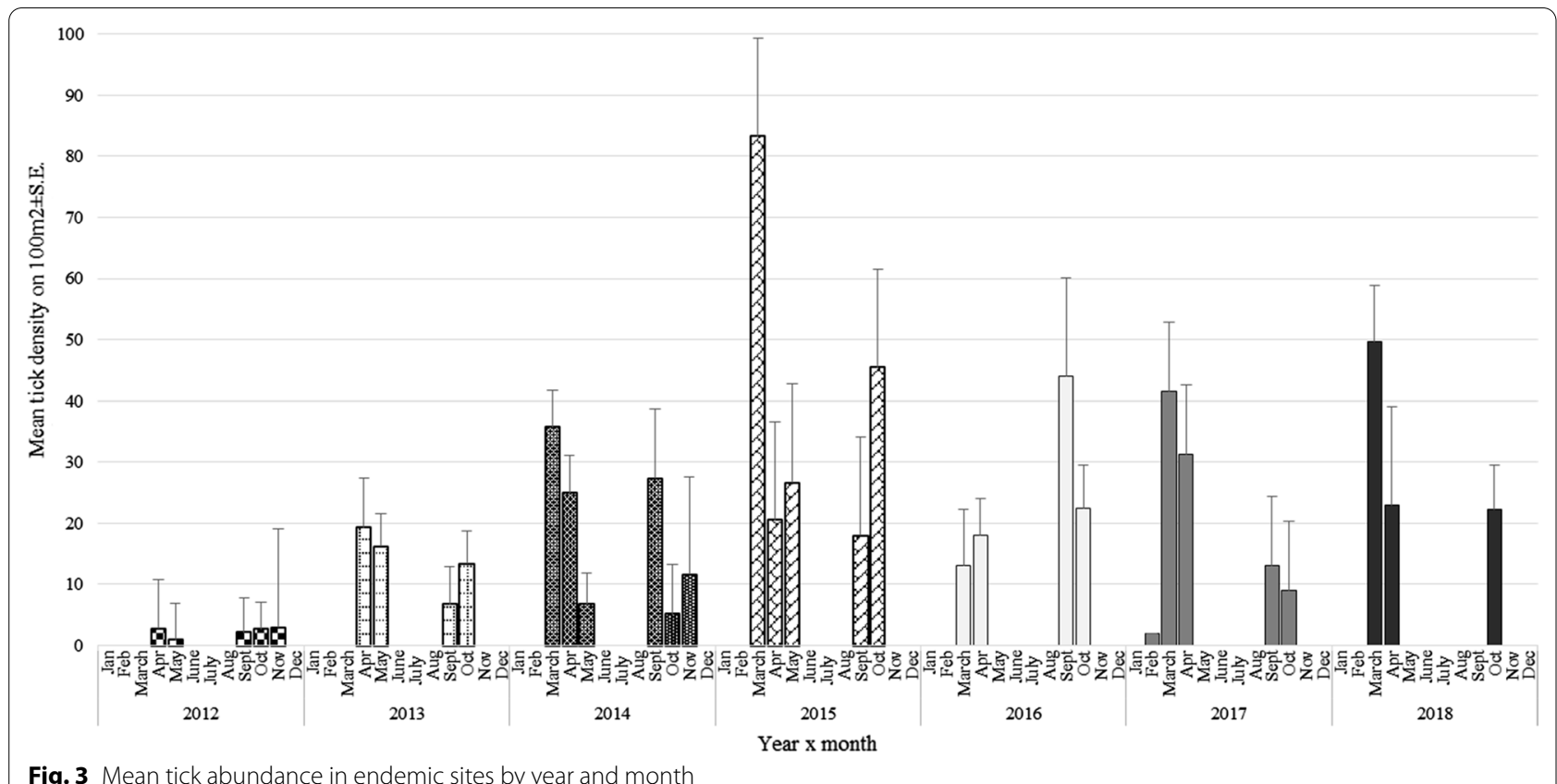

Fig. 3 Mean tick abundance in endemic sites by year and month

\section{Fatality in canine babesiosis}

Fatalities comprised $2.40 \%$ of clinical cases, and similar fatality rates were recorded in Eastern and Central Poland (Table 5). Because of the low number of all cases in the two remaining regions, fatality rates varied between 0.00 and $25.00 \%$ (Table 5).

\section{Seasonal dynamics of clinical babesiosis}

The total number of babesiosis cases recorded in each month in clinics from various regions of Poland is presented in Fig. 5. In all the clinics from the old endemic region (Eastern and Central Poland), a similar pattern of occurrence of babesiosis cases was recorded, clearly reflecting seasonal activity of $D$. reticulatus ticks (Fig. 5a). The number of cases increased from early to late spring, to peak in April-May, and a second (lower) peak was observed in October-November, following a reduction in cases in summer. A similar pattern was observed in the seasonal distribution of babesiosis cases from the new endemic region in Western Poland (Fig. 5b) but no clear pattern was found in the gap zone (Fig. 5c), probably reflecting erratic travelling of dogs/dog owners during the spring-summer period. In the old endemic region of $D$. reticulatus, clinical cases of babesiosis were recorded in all months across the year, including winter (Fig. 5a). Detailed data from each clinic is given in Additional file 2: Figure S1. Total number of fatal cases in the old endemic region followed the seasonal pattern of babesiosis occurrence, peaking in April and October 2018 (Fig. 6).

\section{Discussion}

The present study revealed further expansion of each of the two Polish $D$. reticulatus populations between spring 2016 and autumn 2018, with marked colonization of the gap zone. For the first time, the seasonal shift in the borders of the range of ticks was estimated, suggesting continuing progress of expansion into the future. Data from veterinary clinics revealed a low risk of canine babesiosis in Western Poland and the gap zone, but a high incidence of infection and fatality in Central and Eastern Poland, in the endemic area of the Eastern tick population and its expansion zone. Based on our data, we were able to compile an updated map of the incidence of babesiosis in different regions of Poland, together with the current areas and limits of the occurrence of the tick D. reticulatus.

In comparison to our previous monitoring study in 2012-2014 [2], numerous new D. reticulatus foci were found during the period 2016-2018, with further colonization of the gap zone. Expansion was confirmed both by the detection of new $D$. reticulatus-positive sites in areas previously free of this tick species as confirmed in our earlier study, and by the dynamic changes in the borders of tick ranges (seasonal shift) and the distance separating the two tick populations. The calculation we conducted herein revealed that this tick species is continually expanding its range and is gradually but systematically colonizing the gap zone. The mean shift in the limits of the tick range was clearly higher for the Western population than the Eastern one. Thus, it seems very likely that the $D$. reticulatus-free area is going to disappear in 10-13 


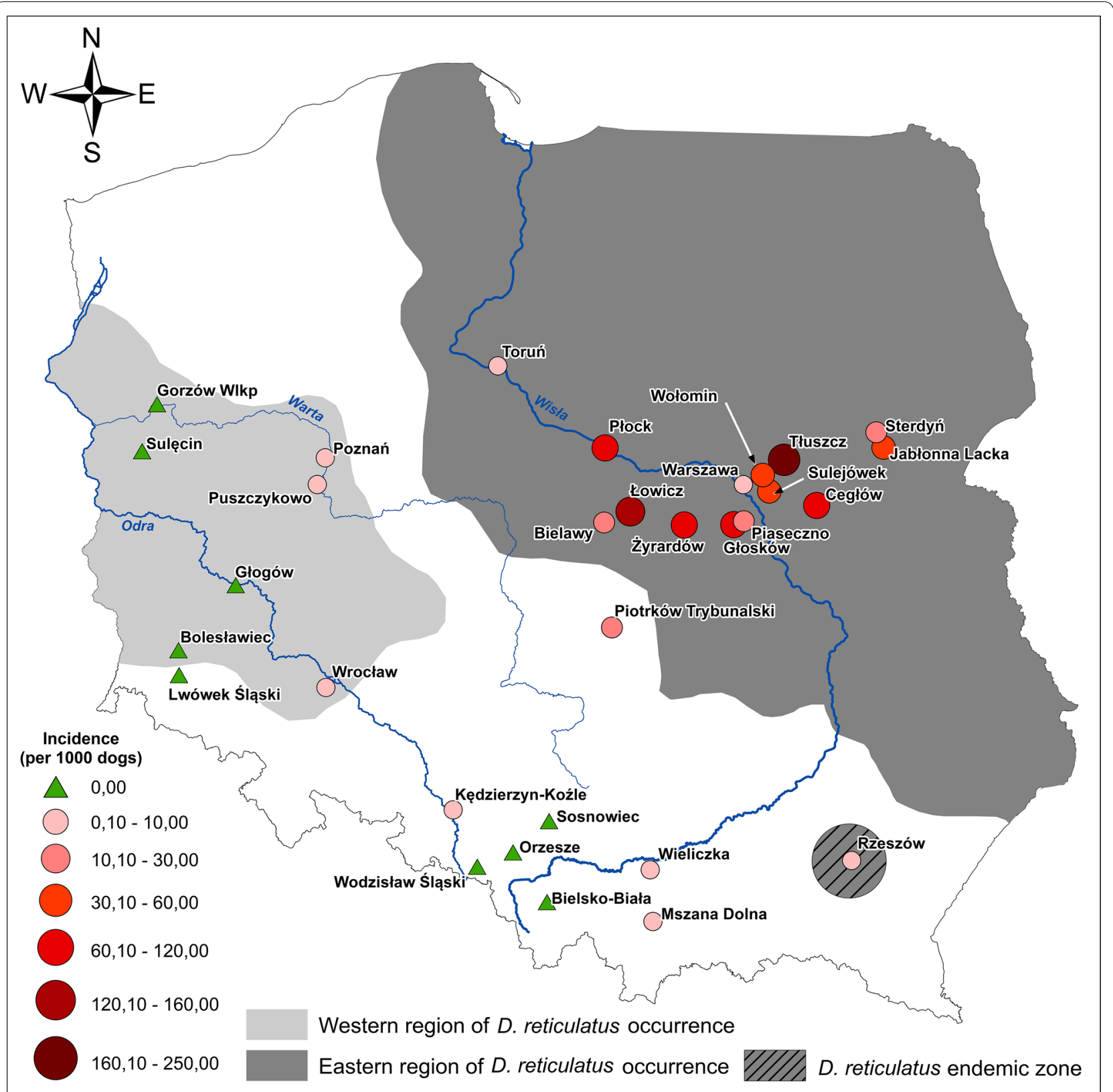

Fig. 4 Incidence (per 1000 dogs) of canine babesiosis in veterinary clinics by current range of $D$. reticulatus

year's time, and the two populations will then meet and merge. It would be of interest to compare this process with reports from other countries in Western, Central and Eastern Europe.

The reasons for the dynamic expansion of this tick species in the area of Central Europe, including Poland, are not understood. Generally, the spread of ticks into new areas is affected by a diverse range of biotic and abiotic factors [43], but knowledge of those factors specific to D. reticulatus is still limited. It has been shown that neither temperature nor duration of the growing seasons is a limiting factor for the spread of D. reticulatus in the territory of Poland [14]. One of the possible causes of tick spread to the new areas might be host mobility [44, 45], as tick hosts (especially medium-size or large mammals) obviously have a greater ability to migrate for longer distances than the ticks themselves. Increasing wildlife populations such as elk (Alces alces), roe deer (Capreolus capreolus) and red deer (Cervus elaphus) in Poland [46], all known to be good hosts for 


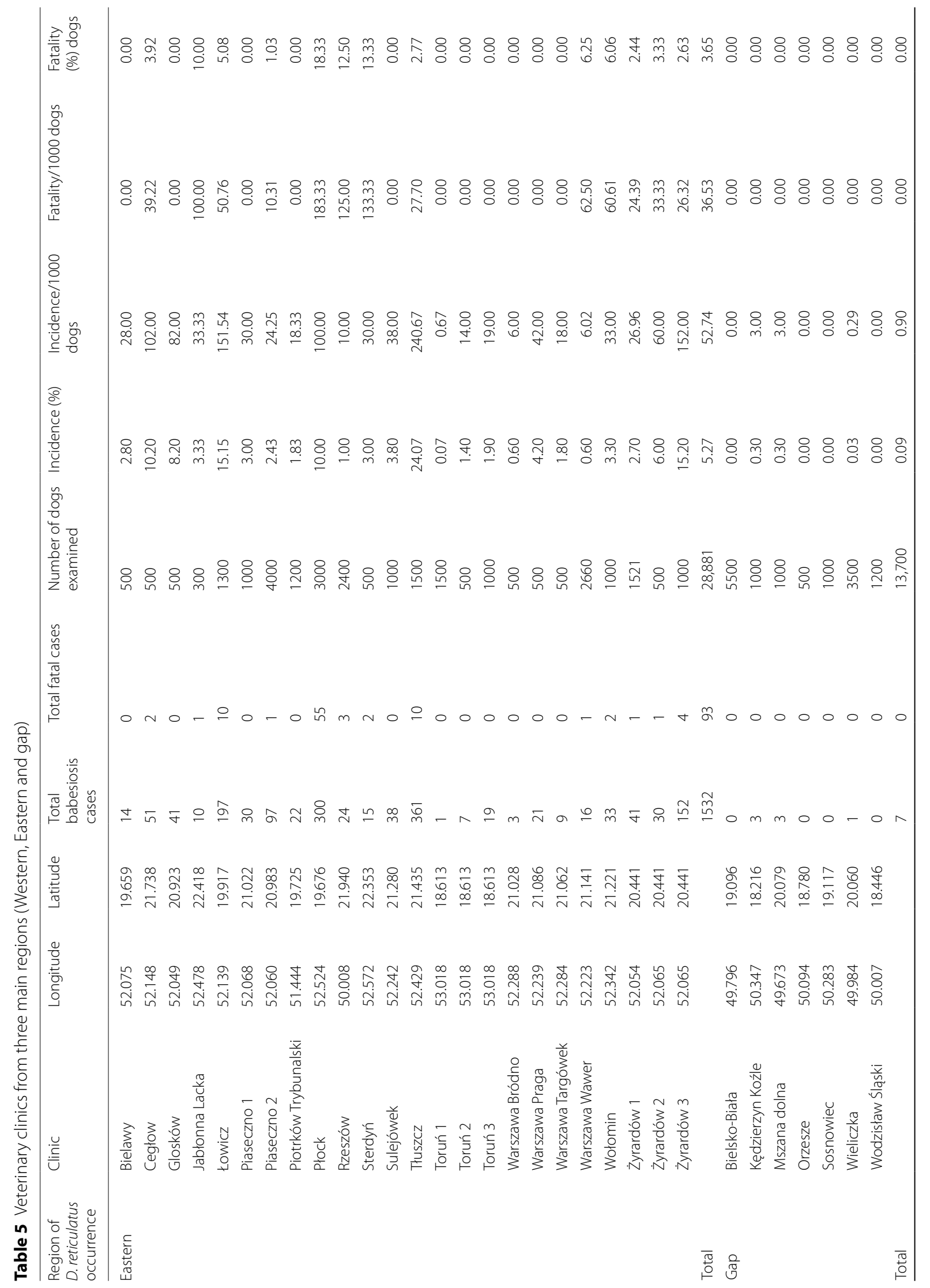




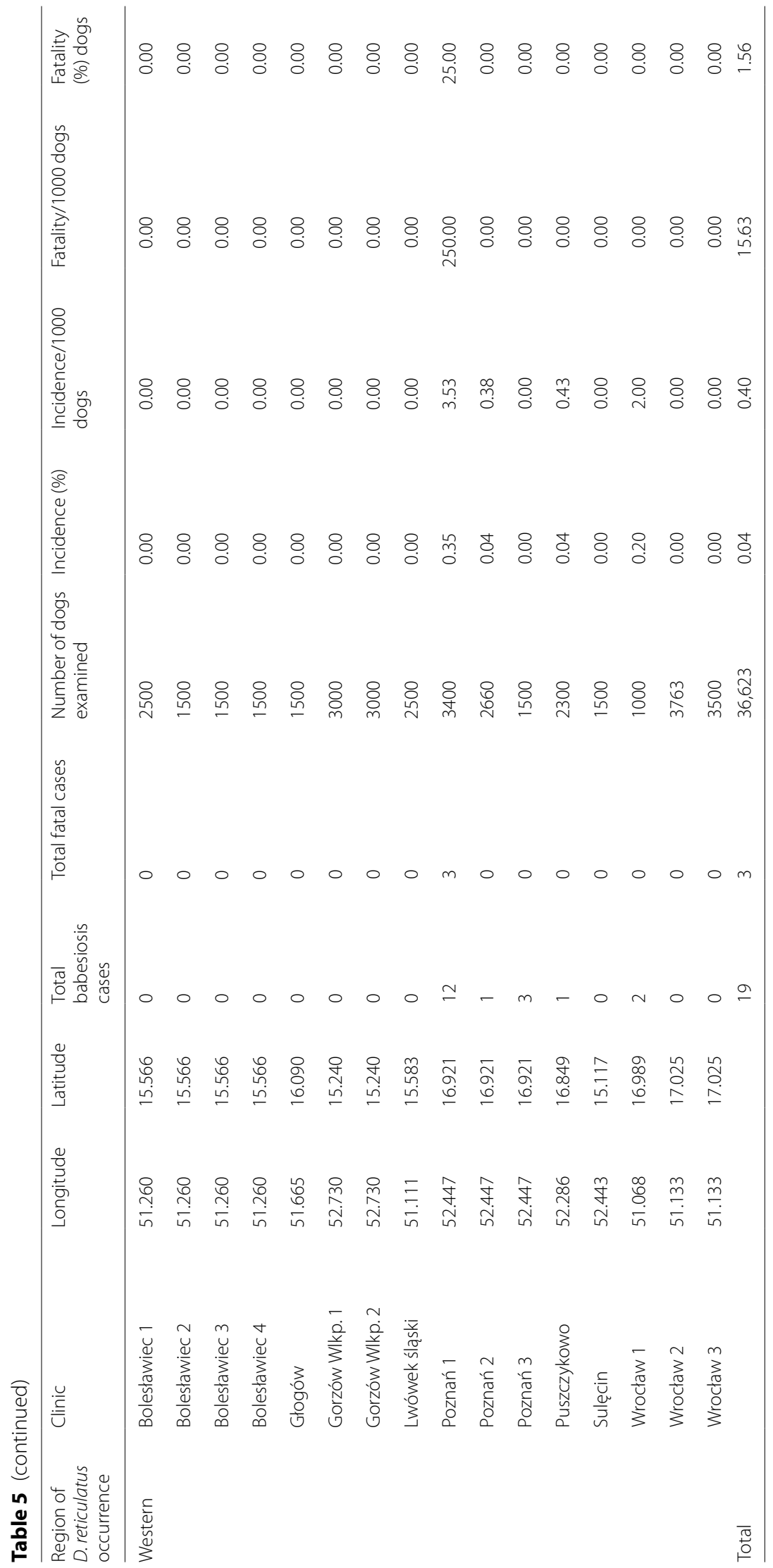




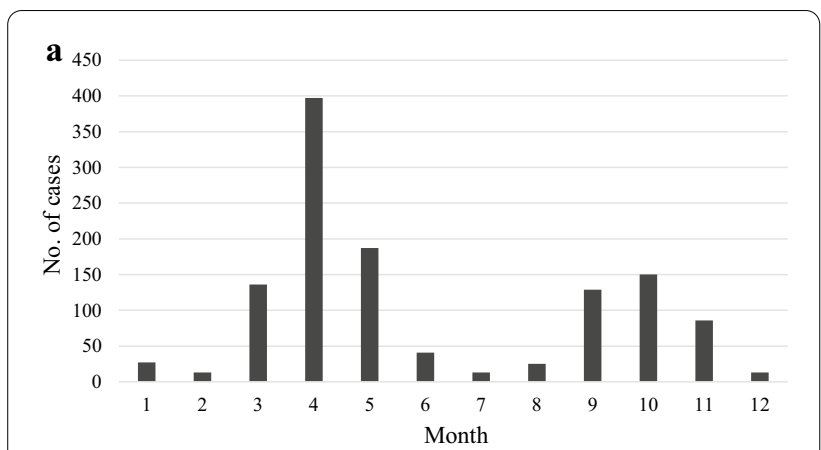

b

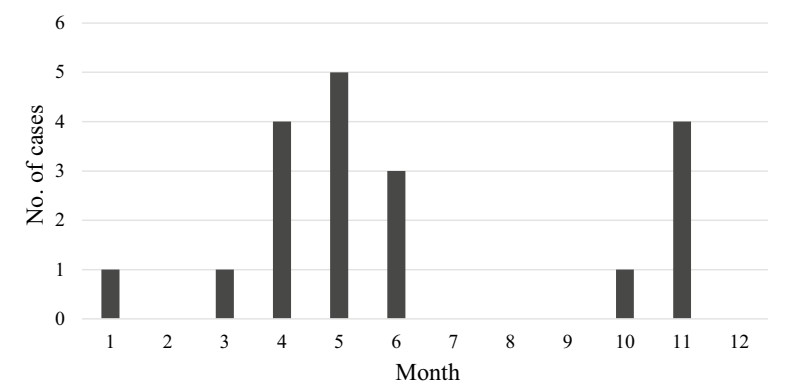

c

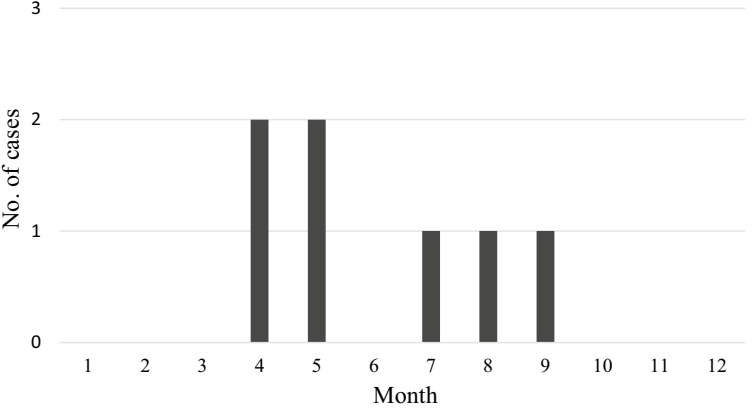

Fig. 5 The number of babesiosis cases recorded in each month from a Eastern region, $\mathbf{b}$ Western region, $\mathbf{c}$ gap region

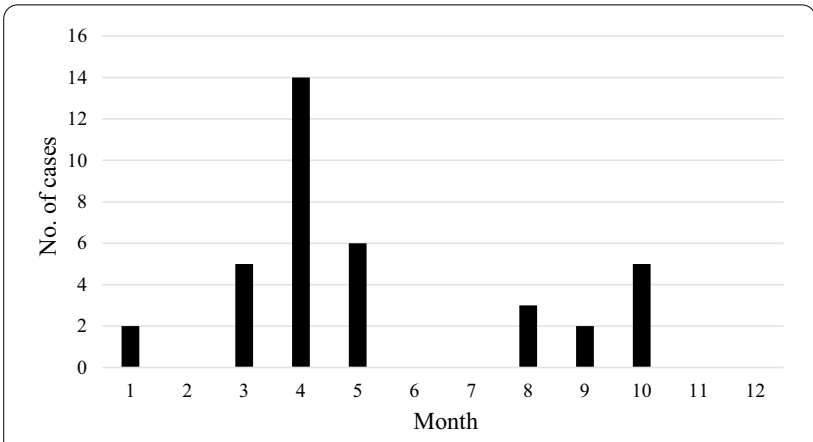

Fig. 6 Number of total fatal cases of babesiosis per month

adult $D$. reticulatus [47-49], can facilitate colonization of the new areas.
In the present monitoring, a few $D$. reticulatus-positive sites appeared in one season and then reverted to negativity in the following seasons. Absence of ticks in the following season can be explained by the lack of appropriate habitats for maintenance of $D$. reticulatus. Occurrence of this tick species is strongly associated with the presence of open habitats (including deforestation), fragmentation of landscape within a large patch of homogeneous vegetation, and the presence of watercourses [14]. The most eastward and westward tick-positive sites for both the Western and Eastern populations were located in Greater Poland Voivodeship, which comprises highly agricultural areas (report from statistical office in Poznań, 2017). A single appearance of D. reticulatus in Sławoszewek (the most westward sites from the Eastern population) was noted at a site surrounded by cereal monocultures and located in close proximity to the KWB Konin SA brown coal opencast mine. It is possible that ticks were carried to this site by a wild animal, but without suitable habitat conditions, maintenance of a new focus of ticks was not possible. The temporal/ephemeral occurrence of ticks in several sites from both expansion zones is also supported by significantly lower densities/abundance of ticks in the expansion zones in comparison to endemic areas.

Interestingly, seasonal shifts in the borders of both tick population ranges were recorded during the present study along the river valleys, and this observation concurs with previous studies $[2,7,12,14,24]$. Thus, on the basis of current trends, we can predict with some confidence that eventually the two populations of $D$. reticulatus will meet in a river valley. The most likely is the Warta River valley-D. reticulatus-positive sites from both Eastern and Western populations were found there, creating one of the shortest distances between the two tick populations and facilitating expansion along a west-east axis (Fig. 1).

Comparison of the occurrence/distribution of both ticks and canine babesiosis clearly demonstrates that expansion of the tick range is accompanied by a concomitant expansion of this important tick-borne disease. Our study revealed a low risk of canine babesiosis in Western Poland and in the gap zone and a high incidence of disease and fatality in Central and Eastern Poland, in the endemic areas of the Eastern tick population and its expansion zone.

As we expected, on the basis of the prevalence B. canis in $D$. reticulatus ticks [23, 24], the highest number of babesiosis cases was reported in the region of endemicity of the Eastern D. reticulatus population. Here, incidence of babesiosis was up to $100 \times$ higher in veterinary clinics compared to those located in the gap zone and Western regions. In another study [31], the number of babesiosis cases was six times higher in dogs in Eastern regions of 
Poland compared to the Western regions. Disparity in occurrence of canine babesiosis cannot be explained by the slightly lower abundance of ticks in Western Poland (present study), but is in accordance with differences in B. canis prevalence in these two tick populations. Babesia canis DNA has been detected only in Central and Eastern Poland (Eastern tick population) and was never detected in large samples of questing $D$. reticulatus collected in Western Poland throughout 2012-2018 (Dwużnik and Kiewra, unpublished data) [15, 27]. Seasonal occurrence of babesiosis in dogs from the Eastern region is strongly associated with a high tick density observed during the spring and autumn tick activity periods. Following Martinod and Gilot [5] and our earlier studies [21], we can define the Central and Eastern region of Poland as a hyperendemic region for canine babesiosis caused by $B$. canis.

Based on feedback from two clinics, one from the gap zone and one from Western region, B. canis infections were identified in dogs with a history of travel to the Eastern region of $D$. reticulatus occurrence. The dogs' travel histories [50] to the B. canis high-risk region and the relatively low number of babesiosis cases in their home territories indicate that the disease was imported to the Western region rather than overlooked earlier locally. On the other hand, the emergence of a new tick-vectored pathogen in regions considered free of ticks may be the first sign of an expanding geographical coverage for this tick species [51]. However, single cases of babesiosis in the Western region suggest importation of infection from the hyperendemic Eastern region rather than established endemicity of babesiosis in the Western population of ticks. Even if B. canis has been established in the Western population, the very low numbers of recorded cases could reflect extremely low $B$. canis prevalence in ticks in this region. In a recent study in Bavaria, Germany (Western metapopulation), only one B. canis-positive tick (0.3\%) was found among 301 questing $D$. reticulatus examined [52]. In contrast, among 60 ticks collected from vegetation in Western Ukraine (Eastern metapopulation), DNA of B. canis was identified in $12 \%$ of ticks [53].

An interesting pattern has been observed in Rzeszów city (at the border of the Carpathian mountain area), where a high incidence of $B$. canis infection in dogs together with the classical seasonal distribution of babesiosis cases suggest that a stable population of $D$. reticulatus occurs in this area. Moreover, new foci of $D$. reticulatus ticks have been observed even further south in the Przemyskie Foothills [54].

The information provided in this paper on the current range of $D$. reticulatus in Poland and the associated map (Fig. 1d) should be of interest in facilitating the prediction of infection risk with other pathogens vectored by this tick species, as for example Rickettsia spp. and tickborne encephalitis virus $[15,55]$.

\section{Conclusions}

In the present study we have determined the actual geographical range of the D. reticulatus tick in Poland and the seasonal/annual shift in limits to its range, and we have documented the continuing process of colonization of the gap zone. Moreover, we have documented the gradual, progressive disappearance of tick-free areas in Central Europe and predicted possible contact of the two tick metapopulations. We have also reported the emergence of canine babesiosis in the expansion zone of the Eastern $D$. reticulatus population and the much lower risk of babesiosis associated with the expansion of the Western tick population. Finally, the updated map of the distribution of $D$. reticulatus and babesiosis in different regions of Poland has allowed the prediction of the emergence of a range of other tick-borne diseases vectored by D. reticulatus.

\section{Abbreviations}

SE: Southeastern; NE: Northeastern; VP: Veterinary practitioners.

\section{Supplementary Information}

The online version contains supplementary material available at https://doi. org/10.1186/s13071-021-04758-7.

Additional file 1: Table S1. Number of collections during the monitoring study.

Additional file 2: Figure S1. Number of babesiosis cases recorded from veterinary clinics (Eastern, Western, gap region) per month.

\section{Acknowledgements}

We sincerely thank Professor Jerzy M. Behnke, University of Nottingham, UK, for the linguistic proofreading of this article. The authors would also like to thank the three anonymous reviewers for their thorough critical reading of the manuscript and whose comments greatly helped to improve and clarify the final version.

Project partners- veterinarian practitioners collecting data on canine babesiosis: DVMs Cibr Dorota, Gruszka Robert, Hejnar Marta, Kalbarczyk Anna, Kałat Jolanta, Olszak Agnieszka, Ostrowska-Połanecka Teresa, Petelicki Marcin, Popławska Maja, Pruś Małgorzata, Rogozińska Małgorzata, Sarna Maciej, Soroka Magdalena, Szczech Szczepan, Trzaska Magdalena, Wąsiatycz Grzegorz.

\section{Authors' contributions}

DDS: data collection and analysis, laboratory and field studies, statistical and geospatial analyses, drafting the manuscript; EJM: data collection and field studies; AR, KG, JBB, DK, NK: data collection; AB: conceptualization, data collection, project funding, supervision. All authors read and approved the final manuscript.

\section{Funding}

The study was funded by the National Science Centre (NCN) Sonata Bis grant no. 2014/14/E/NZ7/00153 (AB)

Availability of data and materials

All data generated or analysed during this study are included in this published article and its additional information files. 


\section{Declarations}

Ethics approval and consent to participate

Not applicable.

\section{Consent for publication}

Not applicable.

\section{Competing interests}

The authors declare that they have no competing interests.

\section{Author details}

${ }^{1}$ Department of Eco-Epidemiology of Parasitic Diseases, Institute of Developmental Biology and Biomedical Sciences, Faculty of Biology, University of Warsaw, Miecznikowa 1, 02-096 Warsaw, Poland. ${ }^{2}$ Department of Pathology and Veterinary Diagnostics, Warsaw University of Life Sciences- SGGW, 159c Nowoursynowska Street, 02-766 Warsaw, Poland. ${ }^{3}$ Department of Parasitology, Institute of Functional Biology and Ecology, Faculty of Biology, University of Warsaw, Warsaw, Poland. ${ }^{4}$ Department of Forest Phytopathology, Faculty of Forestry, Poznań University of Life Sciences, Poznań, Poland. ${ }^{5}$ Department of Microbial Ecology and Environmental Protection, Institute of Genetics and Microbiology, University of Wroclaw, 63/77 Przybyszewskiego Street, 51-148 Wrocław, Poland.

Received: 18 December 2020 Accepted: 29 April 2021

Published online: 20 May 2021

\section{References}

1. Bogdaszewska Z, Karbowiak G, Siuda K. Występowanie i biologia kleszcza łąkowego Dermacentor reticulatus (Fabricius, 1794) w północnowschodniej Polsce. In. Buczek A, Błaszak C. (eds.). Stawonogi. Znaczenie epidemiologiczne. Koliber, Lublin; 2006. p 75-9. (In Polish).

2. Mierzejewska EJ, Estrada-Peña A, Alsarraf M, Kowalec M, Bajer A. Mapping of Dermacentor reticulatus expansion in Poland in 2012-2014. Ticks TickBorne Dis. 2016;7:94-106.

3. Rubel F, Brugger K, Pfeffer M, Chitimia-Dobler L, Didyk JM, Leverenz S, et al. Geographical distribution of Dermacentor marginatus and Dermacentor reticulatus in Europe. Ticks Tick-Borne Dis. 2016;7:224-33.

4. Kloch A, Mierzejewska EJ, Karbowiak G, Slivinska K, Alsarraf M, Rodo A, et al. Origins of recently emerged foci of the tick Dermacentor reticulatus in central Europe inferred from molecular markers. Vet Parasitol. 2017;15:63-9.

5. Martinod S, Gilot B. Epidemiology of canine babesiosis in relation to the activity of Dermacentor reticulatus in southern Jura (France). Exp Appl Acarol. 1991;11:215-22.

6. Heile C, Heydorn AO, Schein E. Dermacentor reticulatus (Fabricius, 1794) distribution, biology and vector for Babesia canis in Germany. Berl Munch Tierarztl Wochenschr. 2006;119:330-4.

7. Bullová E, Lukáň M, Stanko M, Petko B. Spatial distribution of Dermacentor reticulatus tick in Slovakia in the beginning of the 21 st century. Vet Parasitol. 2009;165:357-60.

8. Široký P, Kubelová M, Bednář M, Modrý D, Hubálek Z, Tkadlec E. The distribution and spreading pattern of Dermacentor reticulatus over its threshold area in the Czech Republic-How much is range of this vector expanding? Vet Parasitol. 2011;183:130-5. https://doi.org/10.1016/j. vetpar.2011.07.006.

9. Rar VA, Maksimova TG, Zakharenko LP, Bolykhina SA, Dobrotvorsky AK, Morozova OV. Babesia DNA detection in canine blood and Dermacentor reticulatus ticks in Southwestern Siberia, Russia. Vector Borne Zoonotic Dis. 2005;5:285-7.

10. Radzijevskaja J, Mardosaitè-Busaitienè D, Aleksandravičienė A, Paulauskas A. Investigation of Babesia spp. in sympatric populations of Dermacentor reticulatus and Ixodes ricinus ticks in Lithuania and Latvia. Ticks Tick-Borne Dis. 2017;9:270-4. https://doi.org/10.1016/j.ttbdis.2017.09.013.

11. Reye AL, Stegniy V, Mishaeva NP, Velhin S, Hübschen JM, Ignatyev G, Muller CP. Prevalence of tick-borne pathogens in Ixodes ricinus and Dermacentor reticulatus ticks from different geographical locations in Belarus. PLoS ONE. 2013;8:e54476. https://doi.org/10.1371/journal.pone.0054476.
12. Földvári G, Široký P, Szekeresm S, Majoros G, Sprong H. Dermacentor reticulatus: a vector on the rise. Parasit Vectors. 2016;9:314. https://doi.org/ 10.1186/s13071-016-1599-x

13. Nosek J. The ecology and public health importance of Dermacentor marginatus and D reticulatus ticks in Central Europe. Folia Parasitol (Praha). 1972;19:93-102.

14. Mierzejewska EJ, Estrada-Peña A, Bajer A. Spread of Dermacentor reticulatus is associated with the loss of forest area. Exp Appl Acarol. 2017:72:399-413.

15. Mierzejewska EJ, Pawełczyk A, Radkowski M, Welc-Falęciak R, Bajer A. Pathogens vectored by the tick, Dermacentor reticulatus, in endemic regions and zones of expansion in Poland. Parasit Vectors. 2015;8:490.

16. Mierzejewska EJ, Alsarraf M, Behnke JM, Bajer A. The effect of changes in agricultural practices on the density of Dermacentor reticulatus ticks. Vet Parasitol. 2015;211:259-65.

17. Bajer A, Rodo A, Alsarraf M, Dwuznik D, Behnke JM, Mierzejewska EJ. Abundance of the tick, Dermacentor reticulatus, in an ecosystem of abandoned meadows: experimental intervention and the critical importance of mowing. Vet Parasitol. 2017;246:70-5.

18. Karbowiak G. The occurrence of the Dermacentor reticulatus tickits expansion to new areas and possible causes. Ann Parasitol. 2014;60:37-47

19. Kiewra D, Czulowska A. Evidence for an increased distribution range of Dermacentor reticulatus in south-west Poland. Exp Appl Acarol. 2013;59:501-6. https://doi.org/10.1007/s10493-012-9612-3.

20. Kubiak K, Sielawa H, Dziekońska-Rynko J, Kubiak D, Rydzewska M, Dzika E. Dermacentor reticulatus ticks (Acari: Ixodidae) distribution in northeastern Poland: an endemic area of tick-borne diseases. Exp Appl Acarol. 2018;75:289-98. https://doi.org/10.1007/s10493-018-0274-7.

21. Bajer A, Mierzejewska EJ, Rodo A, Welc-Falęciak R. The risk of vector-borne infections in sled dogs associated with existing and new endemic areas in Poland. Part 2: occurrence and control of babesiosis in a sled dog kennel during a 13-year-long period. Vet Parasitol. 2014;202:234-40.

22. Solano-Gallego L, Sainz Á, Roura X, Estrada-Pena A, Guadalupe M. A review of canine babesiosis: the European perspective. Parasit Vectors. 2016:9:336. https://doi.org/10.1186/s13071-016-1596-0.

23. Dzięgiel B, KubrakT, Adaszek Ł, Dębiak P, Wyłupek D, Bogucka-Kocka A, et al. Prevalence of Babesia canis, Borrelia burgdorferi sensu lato, and Anaplasma phagocytophilum in hard ticks collected from meadows of Lubelskie Voivodship (eastern Poland). Bull Vet Inst Pulawy. 2014;58:29_ 33. https://doi.org/10.2478/bvip-2014-0005.

24. Zygner W, Górski P, Wedrychowicz H. New localities of Dermacentor reticulatus tick (vector of Babesia canis canis) in central and eastern Poland. P J Vet Sci. 2009;12:549-55.

25. Zając Z, Wójcik-Fatla A, Sawczyn A, Cisak E, Sroka J, Kloc A, et al. Prevalence of infections and co-infections with 6 pathogens in Dermacentor reticulatus ticks collected in eastern Poland. Ann Agric Environ Med. 2017;24:26-32.

26. Zając Z, Woźniak A, Kulisz J. Density of Dermacentor reticulatus ticks in Eastern Poland. Int J Env Res Public Health. 2020;17:2814. https://doi.org/ 10.3390/ijerph17082814.

27. Król N, Kiewra D, Lonc E, Janaczyk B, Chodorowska-Skubiszewska A, Dzieciol M, et al. Dermacentor reticulatus (Fabricius, 1794) and Babesia canis (Piana et Galli-Valerio, 1895) as the parasites of companion animals (dogs and cats) in the Wrocław area, south-western Poland. Ann Parasitol. 2016;62:125-30.

28. Caccio SM, Antunovic B, Moretti A, Mangili V, Marinculic A, Baric RR, et al. Molecular characterisation of Babesia canis canis and Babesia canis vogeli from naturally infected European dogs. Vet Parasitol. 2002;106:285-92.

29. Sobczyk AS, Kotomski G, Górski P, Wędrychowicz H. Usefulness of touchdown PCR assay for the diagnosis of atypical cases of Babesia canis canis in dogs. Bull Vet Inst Pulawy. 2005:49:407-10.

30. Adaszek $Ł$, Winiarczyk S. Molecular characterisation of Babesia canis canis isolated from natural infected dogs in Poland. Vet Parasitol. 2008;152:235-41.

31. Adaszek $Ł$, Martinez AC, Winiarczyk S. The factors affecting the distribution of babesiosis in dogs in Poland. Vet Parasitol. 2011;181:160-5.

32. Welc-Falęciak R, Rodo A, Siński E, Bajer A. Babesia canis and other tickborne infections in dogs in Central Poland. Vet Parasitol. 2009;166:191-8.

33. Uilenberg G, Verdiesen PA, Zwart D. Imidocarb: a chemoprophylactic experiment with Babesia canis. Vet O. 1981:3:118-23. 
34. Vial HJ, Gorenflot A. Chemotherapy against babesiosis. Vet Parasitol. 2006;138:147-60.

35. Kirtz G, Leschnik M, Hooijberg E, Tichy A, Leidinger E. In-clinic laboratory diagnosis of canine babesiosis (Babesia canis canis) for veterinary practitioners in Central Europe. Tierarztl Prax Ausg K Kleintiere Heimtiere. 2012;40:87-94.

36. Halos L, Lebert I, Chao I, Vourch G, Ducrot C, Abrial D, et al. Questionnaire-based survey on distribution and clinical incidence of canine babesiosis in France. BMC Vet Res. 2013;9:41. https://doi.org/10.1186/ 1746-6148-9-41.

37. Collett MG. Survey of canine babesiosis in South Africa. J S Afr Vet Assoc. 2000;71:180-6. https://doi.org/10.4102/jsava.v71i3.710.

38. Beugnet $F$, Chalvet-Monfray K. Impact of climate change in the epidemiology of vector-borne diseases in domestic carnivores. Comp Immunol Microbiol Infect Dis. 2013;36:559-66.

39. Sager H, Casati S, Hartmeier G, Sommer B. Autochthone Fälle von caniner Babesiose im Kanton Solothurn. Schweiz Arch Tierh kd. 2005;147:259-65.

40. Schaarschmidt D, Gilli U, Gottstein B, Marreros N, Kuhnert P, Daeppen JA, et al. Questing Dermacentor reticulatus harbouring Babesia canis DNA associated with outbreaks of canine babesiosis in the Swiss Midlands. Ticks Tick-Borne Dis. 2013;4:334-40. https://doi.org/10.1016/j.ttbdis.2013. 01.007.

41. Wright I. Babesiosis in Essex, UK: monitoring and learning lessons from a novel disease outbreak. Parasit Vectors. 2018;11:132. https://doi.org/10. 1186/s13071-018-2718-7.

42. Olivieri E, Zanzani SA, Latrofa MS, Lia RP, Dantas-Torres F, Otranto D, Manfredi MT. The southernmost foci of Dermacentor reticulatus in Italy and associated Babesia canis infection in dogs. Parasit Vectors. 2016;9:213. https://doi.org/10.1186/s13071-016-1502-9.

43. Estrada-Pena A. Climate, niche, ticks, and models: what they are and how we should interpret them. Parasitol Res. 2008:103:87-95.

44. Jaenson TG, Jaenson DG, Eisen L, Petersson E, Lindgren E. Changes in the geographical distribution and abundance of the tick Ixodes ricinus during the past 30 years in Sweden. Parasit Vectors. 2012;5:8. https://doi.org/10. 1186/1756-3305-5-8.

45. Nadolny RM, Gaff HD. Modeling the effects of habitat and hosts on tick Invasions. Letters in Biomathematics. 2018;5:2-29.

46. Panek M. Sytuacja zwierząt łownych w Polsce. Stacja Badawcza PZł w Czempiniu. 2019:3-14. (In Polish).
47. Bogdaszewska Z. Występowanie i ekologia kleszcza łąkowego Dermacentor reticulatus (Fabricius, 1794) w ognisku mazurskim. Cz. IV. Wyniki badań nad określeniem specyficzności żywicielskiej. Wiad Parazytol. 2005;51:3942. (In Polish).

48. Dautel H, Dippel C, Oehme R, Hartelt K, Schettler E. Evidence for an increased geografical of Dermacentor reticulatus in Germany and detection of Rickettsia sp. RpA4. J Med Microbiol. 2006;296:149-56.

49. García-Pérez AL, Oporto B, Espí B, del Cerro A, Barral M, Povedano I, et al. Anaplasmataceae in wild ungulates and carnivores in northern Spain. Ticks Tick-Borne Dis. 2016;7:264-9.

50. Shaw SE, Lerga AI, Williams S, Beugnet F, Birtles RJ, Day MJ, Kenny MJ. Review of exotic infectious diseases in small animals entering the United Kingdom from abroad diagnosed by PCR. Vet Rec. 2003;152:176-7.

51. Otranto D, Wall R. New strategies for the control of arthropod vectors of disease in dogs and cats. Med Vet Entomol. 2008;22:291-302.

52. Silaghi C, Weis L, Pfister K. Dermacentor reticulatus and Babesia canis in Bavaria (Germany) - a georeferenced field study with digital habitat characterization. Pathogens. 2020;9:541.

53. Levytska V, Mushinsky A, Mierzejewska EJ, Bajer A, Dwużnik D, Slivinska K, et al. Comparison of three methods of DNA isolation for PCR study on Babesia spp., Rickettsia spp., Borrelia spp. Annals of Parasitol. 2019;65(Suppl):116.

54. Krzyżanowska K, Żebracka D, Żółkiewicz K, Długosz P, Tarasek P. Nowe stanowiska kleszczy (Acari: Ixodida) na siedliskach kserotermicznych Pogórza Przemyskiego. VI Ogólnopolska Konferencja Młodych Naukowców: Przyroda—Las-Technologia. 2019:61. (In Polish).

55. Ličková M, Fumačová Havlíková S, Sláviková M, Slovák M, Drexler JF, Klempa B. Dermacentor reticulatus is a vector of tick-borne encephalitis virus. Ticks Tick-Borne Dis. 2020;11:101414.

\section{Publisher's Note}

Springer Nature remains neutral with regard to jurisdictional claims in published maps and institutional affiliations.

Ready to submit your research? Choose BMC and benefit from:

- fast, convenient online submission

- thorough peer review by experienced researchers in your field

- rapid publication on acceptance

- support for research data, including large and complex data types

- gold Open Access which fosters wider collaboration and increased citations

- maximum visibility for your research: over $100 \mathrm{M}$ website views per year

At BMC, research is always in progress.

Learn more biomedcentral.com/submissions 